\title{
A socio-metabolic perspective on environmental justice and degrowth movements
}

\author{
Arnim Scheidel ${ }^{* 1}$, Anke Schaffartzik ${ }^{1,2}$ \\ ${ }^{1}$ Institute of Environmental Science and Technology (ICTA), Autonomous University of Barcelona \\ (UAB) Spain. *Corresponding author: arnim.scheidel@gmail.com \\ ${ }^{2}$ Institute of Social Ecology (SEC), University of Natural Resources and Life Sciences Vienna (BOKU), Austria
}

\begin{abstract}
Degrowth and environmental justice movements share overarching aims of sustainability and justice and pursue them through radical social change and resistances. Both movements are diverse and comprised of groups that originate and operate in different contexts. The ever-growing metabolism of the world economy presents an obstacle to both movements' aims, while a socio-metabolic perspective unveils very different characteristics and contexts of the specific struggles. The strategies of many environmental justice movements located at the frontiers of resource extraction are employed to resist coerced socio-ecological transition towards industrialization and to protect more customary ways of life. Movements for the degrowth of industrial metabolism tend to push for socioecological transformation, pursuing new ways of life and reimagined social relations in alternative societies. The overarching aims and obstacles of these movements may be shared, but their struggles, strategies and required actions are not the same. Alliances should seek advantages from this plurality of perspectives and positions within their struggles, while acknowledging potential tensions arising from these different contexts.
\end{abstract}

\section{Keywords}

Social movements; Alliance; Justice; Sustainability; Socio-ecological transitions; Social metabolism 


\section{A socio-metabolic perspective on environmental justice and degrowth}

Growth-led development has turned out to be neither environmentally sustainable nor socially just. Overconsumption in some parts of the world relies on extractive expansion elsewhere, on immense global material use, and on the appropriation of sinks through the discharge of wastes and emissions. In the face of dispossession from livelihood resources, environmental justice movements located at the extractive frontiers seek to assert alternative claims to resources and land (Martinez-Alier et al., 2016; Scheidel et al., 2018). And, as the social and environmental burdens incurred in the name of growth far outweigh the benefits, academics and activists call for degrowth (Demaria et al., 2013).

Does this make grappling with growth one of the "connections between Degrowth and the Environmental Justice movement" that this special section of Ecological Economics is dedicated to exploring? A socio-metabolic perspective that investigates how global to local patterns of resource demand affect movements' concerns, strategies and actions sheds light on some of their commonalities and differences.

Social metabolism refers to the processes of material and energy appropriation, transformation, discharge, and disposal within societies, necessary for their biophysical as well as socio-cultural reproduction. Different socio-metabolic profiles characterize societies' resource use patterns. In socioecological transitions, fundamental changes to the metabolic profile coincide with social, economic and ecological shifts as new production and consumption networks emerge, infrastructures are developed, and trade patterns are redefined (Fischer-Kowalski and Haberl, 2007).

From such a socio-metabolic perspective, we argue that claims from environmental justice and degrowth movements ${ }^{1}$ do not arise independently of the socio-metabolic profiles in which they operate but are strongly shaped by them even as they rally to change them. While both movements face the material needs of the growing world economy as an obstacle to their aims of justice and sustainability, the struggles that different groups lead on the ground take on a variety of forms. Many environmental justice movements located at the extractive frontiers are resistance movements against the growing demand on their resources, land and labour in order to protect their more customary ways of life. Conversely, degrowth movements in industrial countries aim to envision new ways of life and alternative societies that require less resources, but in turn face resistances from consumers and capital's vested interests in general.

In grappling with the material demands of growth globally, degrowth and environmental justice may go hand in hand (Martinez-Alier, 2012), can perhaps not succeed independently of one another (Akbulut et al., this issue). In asserting their specific claims, we argue, however, they must continue to frame their concerns and strategies according to their experiences and their different socio-metabolic contexts. Alliances between the movements must be able to champion this plurality of perspectives and draw on the diversity of corresponding frames, strategies and actions.

\footnotetext{
${ }^{1}$ Both groups of movements are in themselves very diverse. In our argument, we focus on degrowth groups as those investigating and seeking out alternatives to the growth-led society and on environmental justice movements at the frontiers of resource extraction, comprised of heterogeneous groups (indigenous people and traditional communities, peasants and customary forest dwellers, fisher-folks, or other threatened by extractive and polluting industries) defending the environment they depend on for their survival. These groups have also been described as "environmentalists of the poor" (Martinez-Alier, 2002), "ecosystem people" (Gadgil and Guha, 1995), and "environmental defenders" (Global Witness, 2017).
} 


\section{No growth without inequality}

One of the most fundamental consequences of growth-led development has been that global extraction of material resources has been rising exponentially, with accelerated growth since the turn of the century (Krausmann et al., 2018). Much of this growth has failed to reduce international material inequality (Duro et al., 2018). Instead, a variety of socio-metabolic profiles have emerged across the globe that are characterized by distinct levels of resource appropriation, consumption and trade (Schaffartzik et al., 2014), coinciding with political, economic and geographic patterns.

The imperial mode of living - in the wealthy, industrialized economies - is marked by the "unlimited appropriation of resources and labour power" (Brand and Wissen, 2012, p. 547) from other world regions $^{2}$. This hegemonic exertion of imperialism shapes the global economy precisely because it is not universal. The ideal-typical industrial metabolic profile (Schaffartzik et al., 2014) could not exist without net-imports and drastic socio-ecological change at the sites of origin of these imports. Resource appropriation relies on extractivism, dispossession, and the loss of livelihoods elsewhere, that is, on processes integral to growth-led capitalist expansion (Schaffartzik and Pichler, 2017). Through political treaties, legal mechanisms, leases, economic incentives, cultural appeal, and outright violence (Del Bene et al., 2018; Navas et al., 2018; Temper et al., 2015; White et al., 2017), people are firmly nudged, if not coerced, towards a socio-ecological transition. Along this transition, customary socio-metabolic profiles characterized by low levels of dominantly renewable resource consumption are pushed to change towards material- and energy-intensive profiles. Consequently, environmental conflicts over changing resource and land uses and environmental degradation arise frequently (Scheidel et al., 2018).

In response, environmental justice movements located at the extractive frontiers have emerged globally to protest and resist such coerced transitions and the associated upheaval to their livelihoods (Martinez-Alier et al., 2016). They seek the protection of their customary ways of living by maintaining their governance forms and use of natural resources. Because appropriation of resources, land, and labour for consumption is linked to economic growth, many environmental justice movements would clearly benefit from the success of degrowth movements in downscaling material demand. Conversely, by contesting resource appropriation required by economic growth, successful environmental justice movements support degrowth. Both struggles, as far as they can even be homogenized into two groups, face powerful actors protecting their vested interests and (inadvertently) the imperative of growth-led development (Figure 1). From the state to multi-national companies and their local goons to comfortable consumers looking to protect their status quo, the opponents take on very different forms, each requiring an according strategy for the confrontation.

\footnotetext{
${ }^{2}$ There are inequalities both amongst and within these economies. Individuals may, voluntarily or involuntarily, live on the fringes of the system but the vast majority directly and indirectly appropriates resources and labour through consumption.
} 


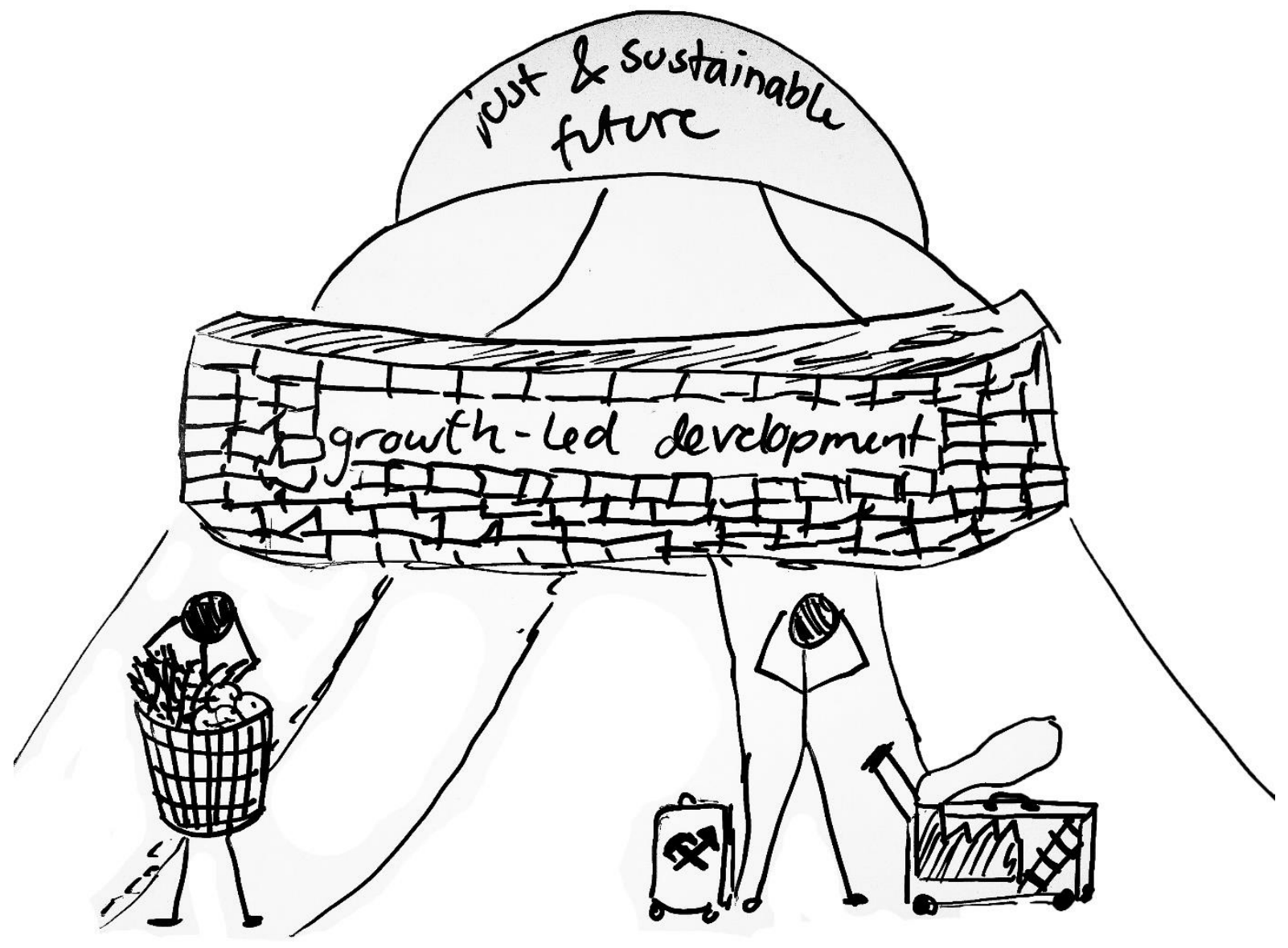

Figure 1: On the path to a just and sustainable future, growth-led development poses obstacles to both those whose environmental rucksack is not much more than a basket of biomass and to those who haul a very heavy suitcase of non-renewable materials around. These travellers will have to choose different routes to reach their shared destination.

\section{Same same, but different?}

Environmental justice and degrowth share overall aims of justice and sustainability and face the same obstacle posed by growth-led development. However, the movements originate and operate in different contexts. Low levels of resource use tend to be the socio-metabolic context of environmental justice movements, while high resource use is more typically prevalent within the degrowth movement. Accordingly, environmental justice and degrowth movements have developed different framings of the problem, as well as strategies and actions in pursuit of their shared overall aims that we summarize in Table 1. 
Table 1: Same same, but different? Commonalities and differences between environmental justice and degrowth movements. In this table, we present an ideal-typical argument that aids our understanding of an, as ever, more complex reality.

\begin{tabular}{|c|c|c|}
\hline & $\begin{array}{l}\text { Environmental justice movements } \\
\text { at extractive frontiers }\end{array}$ & $\begin{array}{l}\text { Degrowth movements in } \\
\text { industrialized economies }\end{array}$ \\
\hline \multirow[t]{2}{*}{ Overall objective } & \multicolumn{2}{|c|}{ Same } \\
\hline & Justice and sustainability. & Sustainability and justice. \\
\hline General obstacle & \multicolumn{2}{|c|}{$\begin{array}{c}\text { Unsustainable and unjust global to local expansion of resource, land, and labor } \\
\text { appropriation through growth-led development. }\end{array}$} \\
\hline \multirow{2}{*}{$\begin{array}{l}\text { Struggle from a socio- } \\
\text { metabolic perspective }\end{array}$} & \multicolumn{2}{|c|}{ Different } \\
\hline & $\begin{array}{l}\text { Resistance against a coerced socio- } \\
\text { metabolic transition towards the } \\
\text { provision of resources, land, and } \\
\text { labor and new consumer markets } \\
\text { within the global economy. }\end{array}$ & $\begin{array}{l}\text { Proposition of a radical socio- } \\
\text { metabolic transformation away from } \\
\text { the industrial, capitalist profile with } \\
\text { its imperial appropriation of } \\
\text { resources, land, and labor. }\end{array}$ \\
\hline \multirow[t]{3}{*}{ Specific aims } & \multicolumn{2}{|c|}{ Different } \\
\hline & $\begin{array}{l}\text { Protection of traditional livelihoods } \\
\text { and ways of living. }\end{array}$ & $\begin{array}{l}\text { Pursuance of new livelihoods and } \\
\text { ways of living, within alternative } \\
\text { societies }\end{array}$ \\
\hline & & $\begin{array}{l}\text { Degrowth of industrial livelihoods } \\
\text { and economies. }\end{array}$ \\
\hline \multirow{2}{*}{$\begin{array}{l}\text { Resulting concepts and } \\
\text { frames, strategies, } \\
\text { collective actions }\end{array}$} & \multicolumn{2}{|c|}{ Different } \\
\hline & $\begin{array}{l}\text { Environmental justice movements } \\
\text { encompass diverse concepts, frames, } \\
\text { strategies, and resistance actions, not } \\
\text { necessarily directly concerned with the } \\
\text { issue of growth (see Rodríguez-Labajos } \\
\text { et al., this issue). }\end{array}$ & $\begin{array}{l}\text { Degrowth movements largely focus } \\
\text { on alternatives to growth, in an } \\
\text { industrialized context } \\
\text { (see Rodríguez-Labajos et al., this } \\
\text { issue). Much emphasis is given on } \\
\text { decolonizing imaginaries of } \\
\text { development and envisioning of } \\
\text { alternative societies. }\end{array}$ \\
\hline
\end{tabular}

Akbulut et al. (this issue, complementarity thesis IV) argue that the differences between the environmental justice and the degrowth movement could not only provide fruitful ground for an alliance but that "[w]ithout a degrowth strategy, EJ movements will never fully succeed and vice versa". The diversity of perspectives can aid the development of new strategies to overcome the shared obstacle posed by the growth imperative (Table 1), so long as these strategies are sensitive to the particular manifestations of growth-led development for these movements. Each socio-metabolic 
context requires specific aims and strategies as well as a manner of communication about the problem that is in keeping with how it is experienced.

The framing in the degrowth movement on growth as the problem may not naturally lend itself to the context of low resource consumption in which environmental justice movements tend to operate, note Rodríguez-Labajos et al. (this issue). For instance, if you have very little in material terms, you might not think of your struggle as one for degrowth, but one of protecting your (sometimes precarious) customary livelihoods and ways of life. This framing also differs from degrowth's strategies of exploring and proposing new ways of life and alternative societies, based on new social relations.

Not only the framings and strategies, but also the challenges on the ground take distinct forms for environmental justice and degrowth movements. Protecting customary livelihoods and land uses under attack by business and the state is a different challenge than the pursuit of decolonizing imaginaries of development and the envisioning of alternative societies based on radical social change, even if they are related and sometimes involve the same types of protest actions, such as street marches, impact monitoring, advocacy, and so on. During such protest actions, loss of livelihood, repression and even murder of protesters occur more frequently in the context of environmental justice movements resisting the expansion of the extractive frontiers. Hence, what is at stake and the potential outcomes differ widely.

Within such struggles, alliances between groups are, however, key to both movement types and may become more important in a context of converging social and environmental crises affecting people across different social groups (Borras et al., 2018).

\section{Environmental justice and degrowth may ally to...}

In light of the shared overall aims and obstacles, as well as the more specific differences on the ground, it is necessary to clarify what an 'alliance' between degrowth and environmental justice movements could actually mean. Alliances do not have to entail assimilation of perspectives. Rather, they may focus on developing coordinated actions between independent actors to their mutual benefit. Both partners must be able to identify the useful synergies from a plurality of approaches and contexts without negating tensions that emerge due to their differences (see Borras, 2016). While concrete sets of strategies and concepts put forward by one movement in a particular context might not necessarily be useful for the other one, they may have important insights to offer one another. An alliance based on collaboration, coordination, and active information exchange could support both movements.

\section{...collaboratively rewrite the history of growth}

Economic growth, unleashing productive as well as destructive forces, has historically relied on ever higher levels and changed compositions of social metabolism. In the mainstream 'success stories' of capitalism, innovation and efficiency and consumer comfort feature prominently, while systematic environmental degradation, the violent transformation of livelihoods, and the very unequal distribution of benefits and burdens are commonly overlooked. Escobar (2012) has provided an 
important alternative narrative on the history of growth-based development in the Global South. Such a rewritten history on growth would also be useful for the Global North.

From a macroeconomic perspective, degrowth research can offer a history of growth not as the neoclassical tale of success and advancement but as a story of power disparities, inequality, and environmental destruction in the name of resource appropriation (Malm, 2016; Mitchell, 2011). Such a history would also cover the many trade-offs of rising material consumption within the wealthy countries themselves - more of a warning than an invitation for "catching up development" (Mies 1993). Such a re-written history of growth could support environmental justice movements by providing them with historic evidence and counterarguments to advocate against aggressive growth policies, usually legitimized by claims of national progress and development, with detrimental effects on marginal groups (Scheidel, 2016).

Many environmental justice struggles illustrate very clearly the disastrous impacts resulting from growth-led development and high levels of material consumption. Environmental justice groups could more systematically facilitate information to degrowth groups that documents these adverse impacts. The visibilization of the adverse social and ecological impacts of a growing global metabolism, as pursued for instance through the Environmental Justice Atlas (www.ejatlas.org) based on the knowledge of local environmental defenders, may feed into the advocacy work of degrowth proponents: These adverse impacts are not singular events caused by bad project management, but are a systemic feature of a growth-based global economy.

\section{...develop an early-warning system for impending appropriation}

In socio-metabolic terms, the countries providing strategic resources to other countries and regions can be identified. This knowledge could be further condensed in a compilation of global ecological macroeconomics. Crises and crashes in the wealthy countries affect their material use patterns, demand changes with growth, conflicts and wars in one region of the world may cause extraction to shift to new frontiers, both geographically and in terms of what is extracted. Degrowth research can provide early warnings of impending resource shortages, price fluctuations, or shifts in demand that may immediately shape the expansion of the extractive frontier and give rise of new environmental injustices. For instance, the expansion of biofuels crops and associated land grabs was well foreseeable with the expansion of biofuels policies globally. Such early warnings from the centres of resource consumption may allow environmental justice organizations to mobilize pre-emptively against upcoming resource grabs and related policies. Preventive mobilizations seem to increase the likelihood of stopping unsustainable extractive projects (Scheidel et al. 2018).

\section{...reframe what sustainability means and reimagine alternative ways of living}

Environmental justice movements often demonstrate how local economies, based on other principles than growth, are making important contributions not just to sustainability but also to the well-being and contentment of the people. Customary indigenous economies and related land uses, for instance, have been absolutely crucial in global biodiversity conservation (Garnett et al., 2018). Social movements have shown to be key in helping to maintain traditional and community-based resource uses through a sustainable governance of the commons (Villamayor-Tomas and García-López, 2018). 
Environmental justice movements located at the extractive frontiers commonly represent diverse claims to maintain lower levels of resource use and the degrowth movements offer a variety of visions for alternative ways of living in industrialized economies, illustrating the wealth of ways in which the shared overarching aim of a sustainable and just future might be approached. ${ }^{3}$ Much further documentation, systematization and sharing of knowledges, resistance strategies and transformation actions from environmental justice and degrowth groups across the globe could be done to visibilize and fully take advantage of the plurality of values and pathways towards sustainability and justice.

In the face of excessive resource use, environmental destruction and social injustices, it sometimes seems as though a new problem pops up behind every solution. But that turns out, at least partly, to be due to the fact that we've been considering a very small (and commodified) pool of potential solutions when there is a whole (shared) ocean of them out there.

\section{Acknowledgements}

Arnim Scheidel acknowledges funding from the European Research Council (ERC) advanced grant ENVJUSTICE (Grant-No. 695446). Anke Schaffartzik acknowledges the financial support from the Spanish Ministry of Economy and Competitiveness, through the 'María de Maeztu' program for Units of Excellence (MDM-2015-0552).

\section{References}

Akbulut B., Demaria F., Gerber J-F, Martínez-Alier J. this issue. Five theses on the relationships between degrowth and the Environmental Justice movement. Ecological Economics. Forthcoming, this issue.

Beckert, S., 2014. Empire of Cotton: A Global History. Knopf Doubleday Publishing Group.

Borras, S.M.J., 2016. Land politics, agrarian movements and scholar-activism. Inaugural Lecture. https://doi.org/10.1017/СВ09781107415324.004

Borras, S.M.J, Moreda, T., Alonso-fradejas, A., Zoe, W., 2018. Converging social justice issues and movements : implications for political actions and research. Third World Q. 39, 1227-1246. https://doi.org/10.1080/01436597.2018.1491301

Brand, U., Wissen, M., 2012. Global Environmental Politics and the Imperial Mode of Living: Articulations of State-Capital Relations in the Multiple Crisis. Globalizations 9, 547-560. https://doi.org/10.1080/14747731.2012.699928

Del Bene, D., Scheidel, A., Temper, L., 2018. More dams, more violence? A global analysis on resistances and repression around conflictive dams through co-produced knowledge. Sustainability Science 13, 617-633. https://doi.org/10.1007/s11625-018-0558-1

\footnotetext{
${ }^{3}$ The recent book 'Pluriverse: A Post-Development Dictionary' edited by Kothari et al. (2018) is a notable example of a collection of transformative alternatives.
} 
Demaria, F., Schneider, F., Sekulova, F., Martinez-Alier, J., 2013. What is degrowth? from an activist slogan to a social movement. Environmental Values 22, 191-215.

https://doi.org/10.3197/096327113X13581561725194

Duro, J.A., Schaffartzik, A., Krausmann, F., 2018. Metabolic Inequality and Its Impact on Efficient Contraction and Convergence of International Material Resource Use. Ecological Economics 145, 430-440. https://doi.org/10.1016/j.ecolecon.2017.11.029

Escobar, A., 2012. Encountering Development: The making and unmaking of the Third World, 2012 Editi. ed. Princeton University Press, Princeton, New Jersey.

Fischer-Kowalski, M., Haberl, H., 2007. Socioecological transitions and global change: trajectories of social metabolism and land use, Advances in Ecological Economics. Edward Elgar Publishing Limited, Cheltenham.

Gadgil M, Guha R, 1995. Ecology and equity: the use and abuse of nature in contemporary India. Routledge, London.

Garnett, S.T., Burgess, N.D., Fa, J.E., Fernández-Llamazares, Á., Molnár, Z., Robinson, C.J., Watson, J.E.M., Zander, K.K., Austin, B., Brondizio, E.S., Collier, N.F., Duncan, T., Ellis, E., Geyle, H., Jackson, M. V., Jonas, H., Malmer, P., McGowan, B., Sivongxay, A., Leiper, I., 2018. A spatial overview of the global importance of Indigenous lands for conservation. Nature Sustainability 1, 369-374. https://doi.org/10.1038/s41893-018-0100-6

Global Witness. 2017. Defenders of the Earth: Global killings of land and environmental defenders in 2016. London.

Kothari, A., Salleh A., Escobar A., Demaria F., and Acosta A., 2018. Pluriverse: A Post-Development Dictionary. Published by Authors Up Front.

Krausmann, F., Lauk, C., Haas, W., Wiedenhofer, D., 2018. From resource extraction to outflows of wastes and emissions: The socioeconomic metabolism of the global economy, 1900-2015. Global Environmental Change 52, 131-140. https://doi.org/10.1016/j.gloenvcha.2018.07.003

Malm, A., 2016. Fossil capital: The rise of steam power and the roots of global warming. Verso Books.

Martinez-Alier, J., 2012. Environmental Justice and Economic Degrowth: An Alliance between Two Movements. Capitalism, Nature, Socialism 23, 51-73.

https://doi.org/10.1080/10455752.2011.648839

Martinez-Alier, J., 2002. The environmentalism of the poor: a study of ecological conflicts and valuation. Edwar Elgar Publishing, Cheltenham.

Martinez-Alier, J., Temper, L., Del Bene, D., Scheidel, A., 2016. Is there a Global Environmental Justice Movement? Journal of Peasant Studies 43, 731-755.

http://dx.doi.org/10.1080/03066150.2016.1141198

Mies, M., 1993. The Myth of Catching-Up Development, in: Ecofeminism. Zed Books, London. Mitchell, T., 2011. Carbon democracy: Political power in the age of oil. Verso Books. 
Navas, G., Mingorría, S., Aguilar, B., 2018. Violence in environmental conflicts: the need for a multidimensional approach. Sustainability Science 13, 649-660. https://doi.org/10.1007/s1162

Rodríguez-Labajos, B., Yánez, I., Bond, P., Greyl, L., Munguti, S., Ojo, G.U., Overbeek, W., 2019. Not So Natural an Alliance? Degrowth and Environmental Justice Movements in the Global South. Ecological Economics 157, 175-184. https://doi.org/10.1016/j.ecolecon.2018.11.007

Schaffartzik, A., Mayer, A., Gingrich, S., Eisenmenger, N., Loy, C., Krausmann, F., 2014. The global metabolic transition: Regional patterns and trends of global material flows, 1950-2010. Global Environmental Change 26, 87-97. https://doi.org/10.1016/j.gloenvcha.2014.03.013

Schaffartzik, A., Pichler, M., 2017. Extractive Economies in Material and Political Terms: Broadening the Analytical Scope. Sustainability 9, 1047. https://doi.org/10.3390/su9071047

Scheidel, A., 2016. Tactics of land capture through claims of poverty reduction in Cambodia. Geoforum 75, 110-114. https://doi.org/10.1016/j.geoforum.2016.06.022

Scheidel, A., Temper, L., Demaria, F., Martínez-Alier, J., 2018. Ecological distribution conflicts as forces for sustainability: an overview and conceptual framework. Sustainability Science 13, 585-598. https://doi.org/10.1007/s11625-017-0526-1

Temper, L., Bene, D., Martinez-Alier, J., 2015. Mapping the frontiers and front lines of global environmental justice: the EJAtlas. Journal of Political Ecology 22, 256-278.

Villamayor-Tomas, S., García-López, G., 2018. Social movements as key actors in governing the commons: Evidence from community-based resource management cases across the world. Global Environmental Change 53, 114-126. https://doi.org/10.1016/j.gloenvcha.2018.09.005

White, B., Jr, S.M.B., Hall, R., Scoones, I., White, B., Jr, S.M.B., Hall, R., Scoones, I., 2017. The new enclosures : critical perspectives on corporate land deals. Journal of Peasant Studies 39, 619-647. https://doi.org/10.1080/03066150.2012.691879 